\title{
Correlation between fission-time and culture-age in the Proliferation of Bacteria.*
}

\author{
By Jun HIRANO**
}

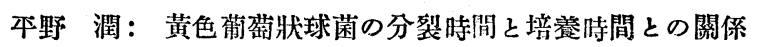

A statistical treatment of the bacterial fission-time has already been made by Kelly \& Rahn'1 in 1932, and discussed later by Hinshelwood2), but in their considerations no account has been made of the change of proliferating activity of bacterial cells with the progress of culture. Since, as is weel known, the bacterial cells gradually change their activity with the age of culture, it seemed worth while to investigate statistically in what manner the bacterial fission-time will be modified with the progress of culture.

\section{Experimental Method}

The method of Kelly \& Rahn1) was adopted with a little modification.

1) Test organism: Staphylococcus aureus FDA $209 \mathrm{P}$.

2) Culture medium: Peptone............. 10. gr.

$\left.\begin{array}{llc}\text { Beef ex.tract } & \ldots . . . & 10 . \mathrm{gr} . \\ \mathrm{NaNO}_{3} & \ldots \ldots \ldots \ldots \ldots & 0.5 \mathrm{gr} . \\ \text { Distilled water } & \ldots & \text { Up to } 1000 \mathrm{ml} .\end{array}\right\}$ Adjusted to $\mathrm{pH} 7.0$.

Solid media were prepared by adding agar-agar to the liquid medium in $2 \%$. Five $\mathrm{ml}$ each of these media were dispensed in an ordinary test-tube and sterilized.

3) Culture and observation: A bacterial suspension which had been kept in a thermostat at $37^{\circ} \mathrm{C}$ for 18 to 24 hours was used for seeding every time. Five loopful of the seeding culture were inoculated into a melted agar-agar medium (cooled to ca. $45^{3}-48^{\circ} \mathrm{C}$ ), which was then well shaken before it solidified. The cultures were then placed in a thermostat at $37^{\circ} \mathrm{C}$.

At different stages of culture, observation of the cell division was started microscopically using a moist chamber as shown in Fig. 1. A glass cylinder $(6 \mathrm{~mm}$ in height and $13 \mathrm{~mm}$ in diameter) was placed on an ordinary slide-glass and covered with a cover-glass. On the under side of the cover-glass a small agar piece taken

* A paper delivered at the Annual Meetings of the Scientific Researches of the Tokyo Institute of Technology, December 19th, 1949; sponcered by the Scientific Rasearch Expenditure of Education Ministry.

** Biochemical Laboratory, Tokyo Institute of Technology. 
Fig. 1. Moist Chamber
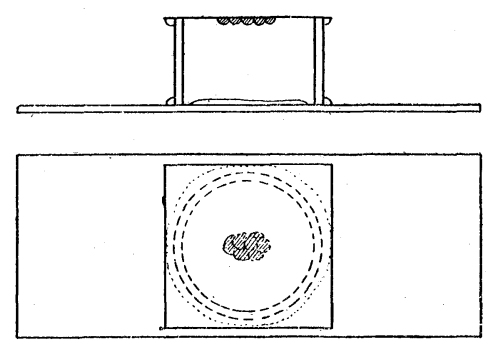

from the agar culture at an appropriate culture age was attached by means of sterile loop and the cell division was observed from above by a microscope with oil immersion. At the bottom of the cylinder a small quantity of the liquid culture medium was placed in order to keep adequate moisture in the chamber. (The contact surfaces of the glass pieces were sealed with vaseline.) During the observation the whole microscope as well as the chamber were

kept at temperature of $33^{\circ}-36^{\circ} \mathrm{C}$.

Observation was made with a number of definite becterial cells found in a suitable field under the microscope. For each individual cell marked, every divisiontime was recorded, which was defined as the time elapsed from the beginning of the original culture to the time when each fission had just completed. Based on these records, the family-trees are constructed, as was done by Kelly \& Rahn ${ }^{1}$. Two examples of such family-trees are shown in Fig. 2, in which the figures represent

Fig. 2. Family Trees

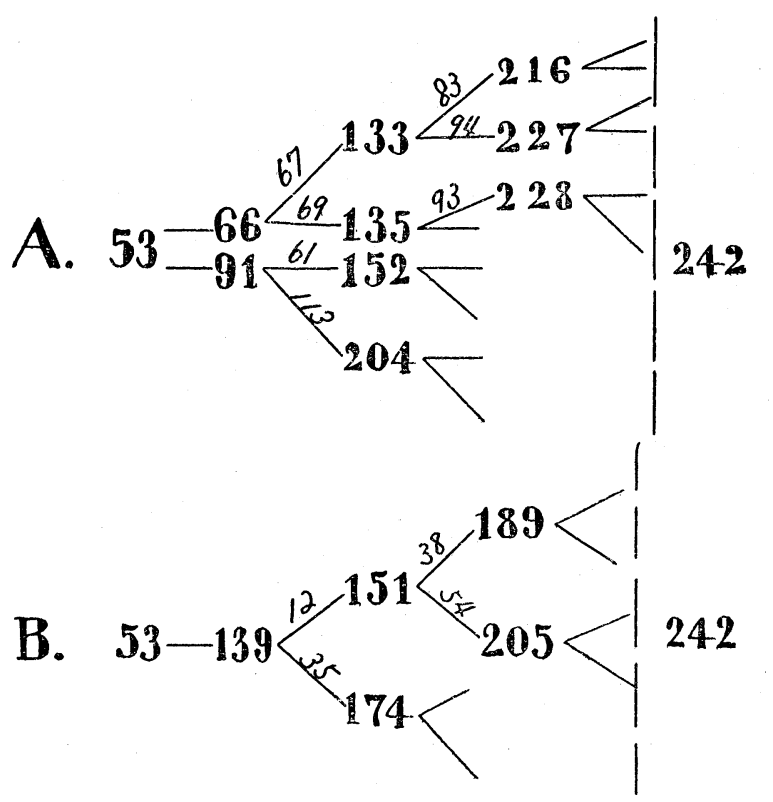
the "division-time" (in minutes) of successive generations. For example, the family-tree " $A$ " was obtained from the following observation: a cluster of two bacteria was selected at culturetime $\mathrm{t}=53$ minutes; one of them divided at $\mathrm{t}=66$, while the other at $\mathrm{t}=91$; the daughters of the former cell divided at $t=133$ and $t=135$, while the daughters of the latter divided at $\mathrm{t}=152$ and $t=204$; and so on. The figures given in small type indicated the "fission-time" which is the interval between two successive divisions.

\section{Results}

Based on the observations which were made during the period of seven months, about two thousand family-tree with 961 data for fission-time were obtained. As was anticipated, the fission-time was found to be, on the whole, a function of culturtime $(t)$, though the values obtained were scattered rather widely. In Fig. 3 , the 
Fig. 3. Correlation Graph between Culture-age and Fission-time.

(Staphylococcus aureus FDA 20 9P, Bouillon Agar: $\mathrm{pH}=7.0$, Temp. $=33^{\circ} \sim 36^{\circ} \mathrm{C}$.

Smallest square $=1$ bacterium. Total $=961$ bacteria.)

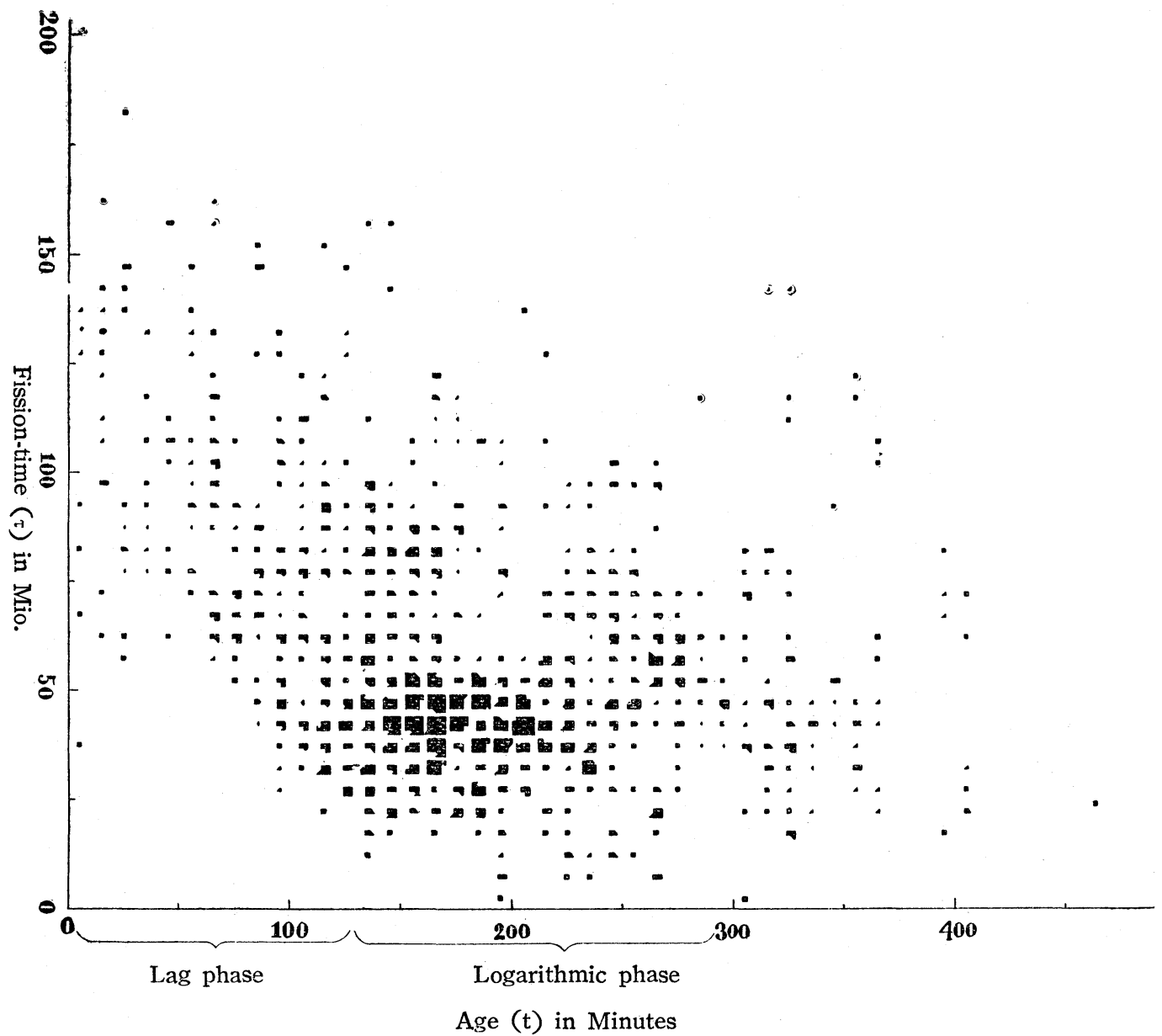

fission-time $(\tau)$ is plotted against the culture-time. The number of obseved cases are expressed by the area of each spot, the smallest squars representing one case observed. The count of the cases. was made with the time units of 10 minutes of culture-time (abscissae) and 5 minutes of fission-time (ordinates). Therefore, those cases which fell just on the borderline of the time sections on either one of the coordinates were counted as $1 / 2$ each for the neighbouring sections, while those cases which fell just on the cross points of the borderlines were counted as $1 / 4$ each for the neighbouring 4 sections. On the abscissa, the approximate time-range of the lagand logarithmic-phases are indicated. It may be seen that the fission-time tends to become smaller in going from lag-phase to logarithmic-phase, where the majority of the cells divided in about 40-50 minutes. The shortest fission-time observed in the 
logarithmic-phase was indeed zero minute.

As regards the phenomenon which occurred after the logarithmic-phase, we could not collect a sufficient number of data, owing to the situation that the cases with large $\tau$-values could not easily be traced in our method, especially in later stages of culture. The distribution of the first division-times after the inoculation is shown in Fig. 4.

Fig. 4. Frequency of First Fission-time.

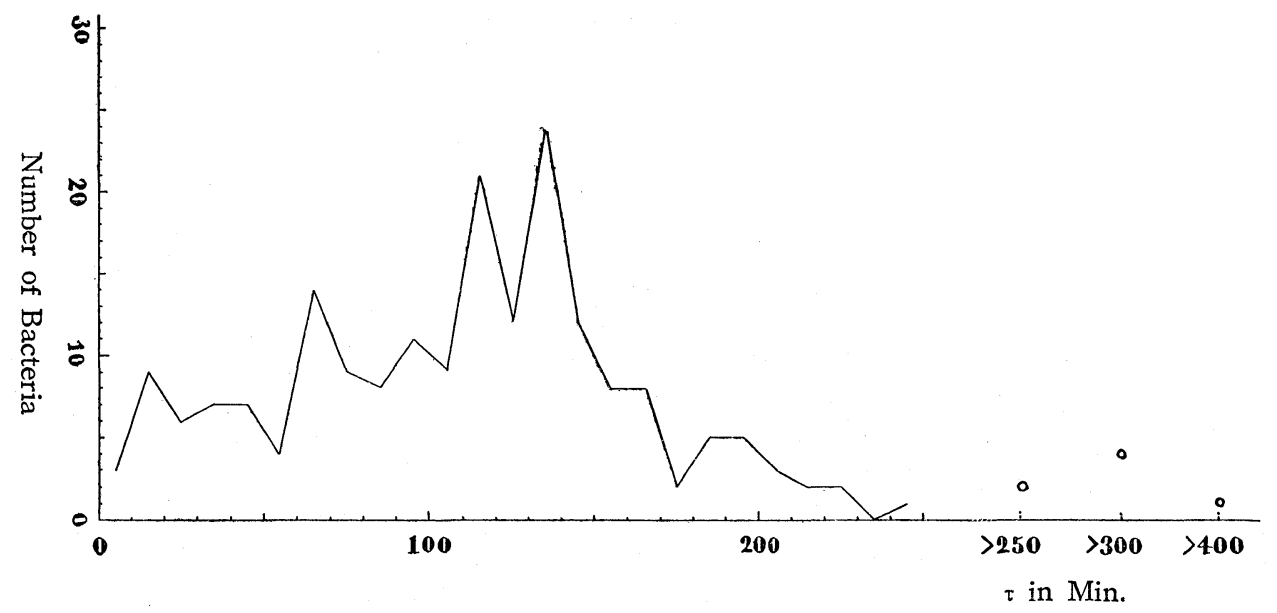

The author is indebted to express here his great gratitude for the kind guidances and encouragements of Prof. Dr. H. TAmrya and Dr. T. Yanagita, Plant Physiological and Microbiological Laboratory, Faculty of Science, Tokyo University, and Prof. Dr. A. Takamiya, Biochemical Laboratory, Tokyo Institute of Technology: thanks are also due to Mr. H. ToyodA and Miss Y. FukudA, for their assistances in the investigation.

\section{References}

1) Kelly, C. D. \& O. RAHN ; J. Bact., 23 (1932), 147.

2) Hinshelwood, C N.; "The Chemical Kinetics of the Bacterial Cell", 1946, page $223 \mathrm{ff}$.

摘要

濕室中に吊した寒天培養基中の黃色葡嘚狀球菌（Staphylococcus aureus FDA 209 P）の 分裂を㙷微鏡で觀察し，その分裂時間と培養持間との記錄をとつて，兩者の關係を調へたをこ ろ，1, 細菌增殖の誘導期に於ては, 分裂特間の分布は全體として次第に短くなつて行くこと, 2, 對數期に於ては殆ど變らないこと, そして此の時期の最も頻度の大きい分裂時間は，この報 告に述べた實驗條件の下では 40〜50 分の間に西つたことがわかつた。 